\title{
TrkB Receptor Signaling Regulates Developmental Death Dynamics, But Not Final Number, of Retinal Ganglion Cells
}

\author{
Graeme S. Pollock, ${ }^{1}$ Regine Robichon, ${ }^{1}$ Kristina A. Boyd, ${ }^{1}$ Kristi A. Kerkel, ${ }^{1}$ Melissa Kramer, ${ }^{1}$ Johnalyn Lyles, ${ }^{1}$ \\ Ranjini Ambalavanar, ${ }^{1}$ Asema Khan, ${ }^{1}$ David R. Kaplan, ${ }^{3}$ Robert W. Williams, ${ }^{4}$ and Douglas 0. Frost ${ }^{1,2}$ \\ ${ }^{1}$ Department of Pharmacology and Experimental Therapeutics, ${ }^{2}$ Neuroscience Program, University of Maryland School of Medicine, Baltimore, Maryland \\ 21201, ${ }^{3}$ Hospital for Sick Children, Department Cancer, Toronto, Ontario M5G 1X8, Canada, ${ }^{4}$ University of Tennessee Health Science Center, Department of \\ Anatomy and Neurobiology, Memphis, Tennessee 38163
}

We investigated the effects of endogenous neurotrophin signaling on the death-survival of immature retinal ganglion cells (RGCs) in vivo. Null mutation of brain-derived neurotrophic factor [(BDNF) alone or in combination with neurotrophin 4 (NT4)] increases the peak rate of developmental RGC death as compared with normal. Null mutation of NT4 alone is ineffective. Null mutation of the full-length trkB $\left(\operatorname{trk} B_{\mathrm{FL}}\right)$ receptor catalytic domain produces a dose-dependent increase in the peak RGC death rate that is negatively correlated with retinal levels of trkB $\mathrm{FL}_{\mathrm{FL}}$ protein and phosphorylated (activated) $\operatorname{trkB}_{\mathrm{FL}}$. Depletion of target-derived trkB ligands by injection of trkB-Fc fusion protein into the superior colliculus increases the peak rate of RGC death compared with trkA-Fc-treated and normal animals. Adult $\operatorname{trkB}_{\mathrm{FL}}{ }^{+/-}$mice have a normal number of RGCs, despite an elevated peak death rate of immature RGCs. Thus, target-derived BDNF modulates the dynamics of developmental RGC death through $\operatorname{trkB}_{\mathrm{FL}}$ activation, but BDNF/trkB-independent mechanisms determine the final number of RGCs.

Key words: neurotrophin; visual system; apoptosis; mouse; hamster; retina; ganglion cell; development; cell death; trkB

\section{Introduction}

An unresolved issue in CNS development concerns the role of target-derived neurotrophins, signaling through their cognate trk receptors and the p75 receptor, as modulators of developmental cell death. Within the peripheral nervous system, immature sensory and sympathetic neurons survive by competing for target-derived neurotrophins (Oppenheim, 1991; Lewin and Barde, 1996; Bibel and Barde, 2000). Few defects have been detected in the CNS of mice with null mutations of single genes for neurotrophins or their receptors. In BDNF and trkB null mutants, the rate of developmental retinal ganglion cell (RGC) death [by an apoptotic process (Rehen and Linden, 1994)] is unknown, but there is no effect on the final number of axons in the optic nerve (Cellerino et al., 1997; Rohrer et al., 2001), which reflects the number of RGCs (Williams et al., 1986). BDNF null mutants exhibit deficits in the differentiation of interneurons (Jones et al., 1994), the maturation of Purkinje cell dendrites (Schwartz et al., 1997), and the myelination of optic nerve axons (Cellerino et al., 1997). In trkB null mutants, there are small increases in

Received May 22, 2003; revised July 24, 2003; accepted July 27, 2003.

This work was supported by National Institutes of Health Grants R01-EY11434 (D.0.F.) and R01-EY12991 (R.W.W.), a Special Research Initiative Support grant from the University of Maryland (D.O.F.), and a Fight for Sight Postdoctoral Fellowship (R.R.). Thanks to David Ginty for pan-trk antibody, to Raquel Aloyz for helpful discussions and advice regarding detection of trkB receptor phosphorylation, and to Bruce Krueger, Bai Lu, Frank Margolis, Barb Rohrer, and Chris von Bartheld for critical comments on this manuscript. We thank David Shelton and Amgen, Inc. for their generous gift of trkA- $\mathrm{Fc}$ and trkB-Fc.

Correspondence should be addressed to Dr. Douglas 0 . Frost, Department of Pharmacology and Experimental Therapeutics, University of Maryland School of Medicine, 655 West Baltimore Street, Baltimore, MD 21201. E-mail: dfrost@umaryland.edu.

Copyright $\odot 2003$ Society for Neuroscience $\quad$ 0270-6474/03/2310137-09\$15.00/0 hippocampal and cerebellar granule cell death rate assayed at selected time points (Alcantara et al., 1997; Minichiello and Klein, 1996).

In vitro, BDNF supports the survival of RGCs (Johnson et al., 1986; Thanos et al., 1988; Castillo et al., 1994) and many other central neurons, including basal forebrain cholinergic neurons, cortical neurons, hippocampal neurons, nigral dopaminergic neurons, and motor neurons (Korsching, 1993; Ghosh et al., 1994). There is limited evidence, however, that endogenous, target-derived neurotrophins modulate normal developmental death among immature central neurons (von Bartheld and Johnson, 2001).

The spatial and temporal patterns of neurotrophin and trk receptor expression are consistent with a death-inhibiting action of endogenous neurotrophins on RGCs: trkA, trkB, and trkC are expressed in developing rodent RGCs (Ernfors et al., 1992; Zanellato et al., 1993; Koide et al., 1995; Rickman and Brecha, 1995; Ugolini et al., 1995). TrkB is also expressed in mature rodent (Jelsma et al., 1993; Suzuki et al., 1998) and developing ferret (Allendoerfer et al., 1994) RGCs. Immature chick and Xenopus RGCs express trkB and trkC (Rodriguez-Tebar et al., 1993; Cohen-Cory and Fraser, 1994; Escandon et al., 1994; Okazawa et al., 1994; Garner et al., 1996; Hallbook et al., 1996). In the developing rodent $\mathrm{SC}, \mathrm{BDNF}$ protein is elevated during the interval when RGCs are eliminated and subsequently falls (Frost et al., 2001). Similarly, in the chick tectum, BDNF protein concentrations increase from embryonic day 4 through hatching (Johnson et al., 2003); this epoch includes the period when developmental $\mathrm{RGC}$ death is maximal. BDNF is present in the mature rodent superior colliculus (SC) (Hofer et al., 1990; Wetmore et al., 1990; 
Frost et al., 2001). Intracollicularly injected BDNF is internalized at RGC axon terminals and retrogradely transported by RGCs (Fournier et al., 1997; Herzog and von Bartheld, 1998; Ma et al., 1998). BDNF is also expressed in the RGC layer and other layers of the rodent retina (Perez and Caminos, 1995; Bennett et al., 1999; Frost et al., 2001; Pollock et al., 2001), which allows for autocrine and paracrine effects.

Here we use null mutations of the genes for BDNF, NT4, or trkB, as well as intrathecal injection of trkB-Fc receptor bodies, to study the effects of endogenous, targetderived neurotrophins on the developmental death of RGCs in vivo. Our data demonstrate that BDNF signaling through the full-length $\operatorname{trkB}\left(\operatorname{trkB} \mathrm{FL}_{\mathrm{FL}}\right)$ receptor modulates the dynamics of developmental RGC death, but trkB signaling has no effect on the final number of RGCs.

\section{Materials and Methods}

Materials. The trkA-Fc and trkB-Fc receptor bodies are fusion proteins consisting of two trkA (or trkB) extracellular domains in tandem with an Fc fragment (Shelton et al., 1995). They were gifts of Genentech, Inc. (San Francisco, CA). The rabbit polyclonal anti-pan-trk antibody, which recognizes an epitope on the cytoplasmic domain common to all full-length trk receptors, was a gift from Dr. David Ginty (Johns Hopkins Medical Institute, Baltimore, MD). The rabbit polyclonal antibody against phosphorylated trk receptors [(anti-Ptrk) which recognizes phosphorylated tyr 490 within the Shc recognition motif of $\operatorname{trkA},-B$, and $-C$ ] and the mouse monoclonal (IgG1) antibody against the extracellular domain of the trkB receptor were purchased from Cell Signaling Technologies (Beverly, MA) and Transduction Laboratories (Lexington, KY), respectively. Chemiluminescent substrate (ECL) and high-range molecular weight markers were purchased from Amersham Biosciences (Piscataway, NJ). Platinum Taq Polymerase was purchased from Invitrogen (Gaithersburg, MD). Anti-mouse IgG peroxidase-conjugated antibody and other reagents were purchased from Sigma (St. Louis, MO).

Subjects and surgery. 129/C57BL/6 mice (mus musculus) and Syrian golden hamsters (Mesocricetus auratus) were subjects in this study. Mice with null mutations of BDNF and NT4 (Conover et al., 1995) were a gift of Regeneron Pharmaceuticals. Mice with null mutations of the trkB catalytic domain (Klein et al., 1993) were purchased from Jackson Laboratories (Bar Harbor ME; catalog \#003098). Hamsters were purchased from Charles River. Because the 129 mouse lines used to make the 129/ C57BL/6 hybrids differed between the Regeneron mice and the Jackson Laboratories mice, separate wild-type (WT) control groups were studied for comparison with the respective mutant lines. In rodents, because virtually all RGCs project to the SC (Linden and Esberard, 1987), RGC nuclei can be selectively labeled by retrograde transport of intracollicularly injected diamidino yellow (DY) (Keizer et al., 1983). Thus neonatal mice and hamsters were anesthetized by hypothermia, the scalp was incised, a glass pipette (tip diameter $50 \mu \mathrm{m}$ ) was lowered through a small hole in the skull, and $0.1 \mu \mathrm{l}$ of DY $\left(2 \%\right.$ in $\left.\mathrm{H}_{2} \mathrm{O}\right)$ was injected bilaterally at a site near the center of the SC and $400 \mu \mathrm{m}$ deep to the dorsal surface. Each injection was made over 2 min using a Picospritzer. At the end of each injection, the pipette was left in situ for 2 min before being withdrawn slowly, to minimize reflux. The scalp was sutured shut, and the animals were reanimated and returned to their mothers.

Previous studies differ as to whether the peak of murine RGC death occurs on postnatal $(\mathrm{P})$ day 2 (first $24 \mathrm{hr}$ after birth $=\mathrm{P} 0$ ) (Young, 1984) or P6 (Linden and Pinto, 1985; Williams et al., 1996). Therefore, we determined the frequency of pyknotic RGCs on P2 and P6 in mice that were treated with DY, as above, on P1 and P2, respectively. Hamsters were treated with DY on P1, and the rate of developmental RGC death
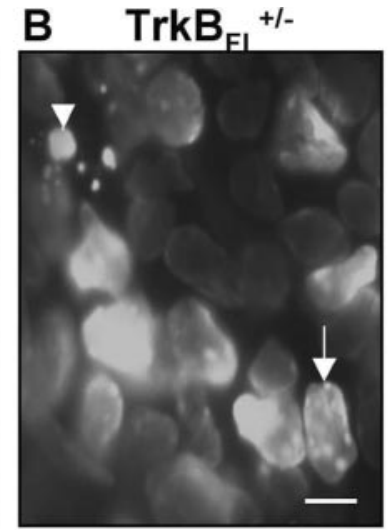
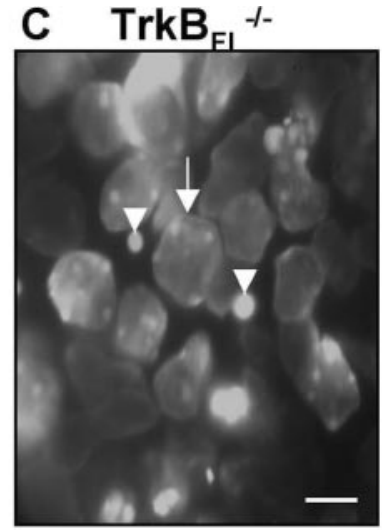

$5 \mu \mathrm{m}$

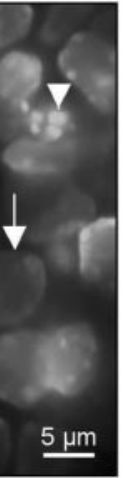

show, respectively, WT, trkB $B^{+/-}$and $\mathrm{trkB}_{\mathrm{FL}}{ }^{-l-}$ mice on P2. Arrows indicate healthy nuclei. Arrowheads indicate pyknotic nuclei in which the chromatin is condensed into single round balls or clusters of multiple smaller balls.

was determined on the day of its normal maximum, P4 (Sengelaub et al., 1986). We demonstrated previously that intracollicular BDNF injections on P3 significantly reduce RGC death at $20 \mathrm{hr}$ latency, on P4 (Ma et al., 1998). Therefore, on P3, $20 \mathrm{hr}$ before being killed on P4, DY-injected hamsters were anesthetized by Halothane inhalation $\left(0.5-1.5 \%\right.$ in $\left.\mathrm{O}_{2}\right)$. TrkB-Fc (Shelton et al., 1995) (18.7 $\mu \mathrm{M}$ in $0.1 \%$ BSA in PBS; $1 \mu \mathrm{l}$ per SC) or, as a control, trkA-Fc (Shelton et al., 1995) (18.7 $\mu \mathrm{M}$ in $0.1 \%$ BSA in PBS; $1 \mu \mathrm{l}$ per SC) was pressure injected bilaterally into the SC (three sites per SC spaced equidistantly from each other and from the border of the SC and $400 \mu \mathrm{m}$ deep to the dorsal surface). This procedure assured that the axons of both ipsilaterally and contralaterally projecting RGCs were exposed to receptor bodies. Additional DY-treated hamsters were killed on $\mathrm{P} 4$ without fusion protein treatment.

Quantitative analysis of the rate of RGC pyknosis. All animals were given an overdose of Nembutal anesthesia (intraperitoneally) and perfused transcardially with $4 \%(\mathrm{w} / \mathrm{v})$ paraformaldehyde in $\mathrm{PO}_{4}$ buffer $(0.1 \mathrm{M}, \mathrm{pH}$ 7.4). Their eyes were enucleated, the cornea, iris, lens, and vitreous were rapidly removed from each eye, and the retina was dissected from the eye cup in cold $\mathrm{PO}_{4}$ buffer $\left(0.1 \mathrm{M}, \mathrm{pH} 7.4,4^{\circ} \mathrm{C}\right)$. Four relieving cuts were made along radii lying at $45^{\circ}$ angles to the principal axes of the retina. The retinas were whole mounted, vitreal side up, on squares of black nitrocellulose paper, placed on a glass slide, and coverslipped with glycerolgelatin. Some WT mouse retinas were stained after dissection with Hoechst dye $(0.1 \mathrm{mg} / 100 \mathrm{ml} ; 3 \mathrm{hr}$, room temperature $)$ and rinsed in PBS before they were mounted on nitrocellulose paper.

The retinas of all DY-treated animals were initially surveyed to verify that RGC nuclei were uniformly labeled across the retina. Retinas not meeting this criterion were discarded. To avoid any bias in the results, we used a blind data collection technique: all retinas used for nuclear counts were coded so that the persons doing the counting did not know the treatment history or genotype of the animals from which the retinas were obtained; no results were revealed to the counters until the completion of data collection for the entire study.

Using a computer-assisted fluorescent microscope system (Neurotrace) equipped with a $100 \times$ oil immersion objective and an ultraviolet filter set, we counted the number of healthy (chromatin not clumped) (Fig. 1) nuclei and the number of pyknotic (clumped chromatin) (Fig. 1) nuclei in a square sampling region within each quadrant. Previous studies have shown that there is a 1:1 correspondence between DY-labeled pyknotic nuclei and pyknotic nuclei labeled by Nissl stains (Harvey et al., 1990). Healthy and pyknotic RGC nuclei have the same respective appearances in WT and mutant mice (Fig. 1). Because retinal surface areas in hamsters are bigger than in mice, sampling regions of different size were used. For hamsters, sampling regions were each 57,600 $\mu \mathrm{m}^{2}$ and centered $\sim 0.92 \mathrm{~mm}$ from the optic disc along radii directed toward the dorsal, ventral, temporal, and nasal poles of the eye. For mice, sampling regions were each $44,100 \mu \mathrm{m}^{2}$ and centered $\sim 0.77 \mathrm{~mm}$ from the optic disc. For each sampling region (or for all four sampling regions pooled 
together), the number of pyknotic nuclei is divided by the total number of nuclei (healthy plus pyknotic) to obtain the fraction of RGCs that are pyknotic. This index is a linear measure of the rate of RGC death and is more reliable than counts of the total number of pyknotic nuclei for which there is significantly more interanimal variability (Harvey et al., 1990; Harvey and Robertson, 1992; Ma et al., 1998). Different experimental groups were compared with respect to the frequency of pyknotic nuclei using the Mann-Whitney $U$ test (two-tailed). To assure consistency among observers in their criteria for identifying normal and pyknotic RGCs, retinas were randomly selected and recounted blind by a different observer at the completion of the study. The fractions of pyknotic RGCs obtained by different observers fell within $4 \%$ of each other.

Determination of mouse genotype. Mice were overdosed with Nembutal. Just before perfusion, the tail and one hindleg were removed to obtain tissue for DNA extraction using QIAamp DNA mini kits (Qiagen Inc., Valencia, CA) following the manufacturer's procedures. PCR amplification of DNA coding trkB $\mathrm{FL}_{\mathrm{FL}}$, BDNF, and NT4 was performed using protocols supplied by the Jackson Laboratory. For amplification of DNA coding $\operatorname{trkB}_{\mathrm{FL}}$, the oligonucleotide primers (one $5^{\prime}$ primer for $\mathrm{WT}$, one for mutant trkB $\mathrm{B}_{\mathrm{FL}}$, and a common $3^{\prime}$ primer) contained the following sequences: primer 1: 5'-TCGCGTAAAGACGGAACATGATCC-3'; primer 2: 5' -AGACCATGATGAGTGGGTCGC-3'; primer $3: 5^{\prime}$-GATGTGGAATGTGTGCGAGGC- $3^{\prime}$

PCR was run under the following conditions: $1.0 \mu \mathrm{l}$ DNA $(1 \mathrm{mg} / \mathrm{ml})$, $0.5 \mu \mathrm{l}$ of each oligonucleotide $(0.5 \mu \mathrm{M}), 0.5 \mu \mathrm{l}$ Platinum Taq Polymerase, $\mathrm{MgCl}_{2}(1.5 \mathrm{~mm})$, and dNTP mix $(0.2 \mathrm{~mm})$ in a total volume of $50 \mu \mathrm{l}$; denature $1 \mathrm{~min}$ at $94^{\circ} \mathrm{C}$; anneal $30 \mathrm{sec}$ at $65^{\circ} \mathrm{C}$, and extend $1 \mathrm{~min}$ at $72^{\circ} \mathrm{C}$. The reaction was repeated for 40 cycles. For amplification of DNA coding BDNF and NT4, the oligonucleotide primers contained the following sequences: BDNF, primer 1, 5'-CATACTTCGGTTGCATG-3', primer 2, 5'-ACTGTCACACACGCTCA-3', primer 3, 5' -ATGGAAGGATTGGAGCTA-3'; NT4, primer 1, 5'-GATCGTATGCGACGCAGTGAGT-3', primer 2, 5'-GATCGACTGCTTAGCCTTGCAT-3', primer 3, 5' -CACCAAAGAACGGAGCCGGTT-3'.

For amplification of DNA coding BDNF, the PCR was run as follows: $2.0 \mu \mathrm{l} \mathrm{DNA}(1 \mathrm{mg} / \mathrm{ml}), 0.9 \mu \mathrm{l}(0.5 \mu \mathrm{M})$ of each primer, $0.06 \mu$ l Platinum Taq Polymerase, $\mathrm{MgCl}_{2}(2.5 \mathrm{~mm})$, and dNTP mix $(0.24 \mathrm{~mm})$ in a total volume of $22 \mu \mathrm{l}$ : denature $1 \mathrm{~min}$ at $94^{\circ} \mathrm{C}$; anneal $2 \mathrm{~min}$ at $57^{\circ} \mathrm{C}$, and extend $5 \mathrm{~min}$ at $72^{\circ} \mathrm{C}(1 \mathrm{cycle})$; denature $1.5 \mathrm{~min}$ at $94^{\circ} \mathrm{C}$; anneal $2 \mathrm{~min}$ at $57^{\circ} \mathrm{C}$, and extend $3 \mathrm{~min}$ at $72^{\circ} \mathrm{C}$ ( 40 cycles). For amplification of DNA coding NT4, the PCR was run as follows: $2.0 \mu \mathrm{l} \mathrm{DNA}(1 \mathrm{mg} / \mathrm{ml}), 0.9 \mu \mathrm{l}$ $(0.5 \mu \mathrm{M})$ of each primer, $0.06 \mu$ l Platinum Taq Polymerase, $\mathrm{MgCl}_{2}(2.4$ $\mathrm{mm})$, and dNTP mix $(0.24 \mathrm{~mm})$ in a total volume of $20 \mu \mathrm{l}$ : denature $1 \mathrm{~min}$ at $94^{\circ} \mathrm{C}$; anneal $2 \mathrm{~min}$ at $58^{\circ} \mathrm{C}$, and extend $5 \mathrm{~min} @ 72^{\circ} \mathrm{C}(1$ cycle $)$; denature $1.5 \mathrm{~min}$ at $94^{\circ} \mathrm{C}$; anneal $2 \mathrm{~min}$ at $58^{\circ} \mathrm{C}$, and extend $3 \mathrm{~min}$ at $72^{\circ} \mathrm{C}$ ( 40 cycles). All reaction products were electrophoresed on a 1.0\% agarose gel.

The 900 and $1000 \mathrm{bp}$ amplicons identified the WT and mutated trkB $\mathrm{B}_{\mathrm{FL}}$ alleles, respectively. The 400 and $200 \mathrm{bp}$ amplicons identified the WT and mutated BDNF alleles, respectively. The 238 and 320 bp amplicons identified the WT and mutated NT4 alleles, respectively.

Immunoprecipitation and Western blot analysis. Mice were killed by decapitation on $\mathrm{P} 2$. The retinas were dissected from the eye cups in cold $\mathrm{PO}_{4}$ buffer $\left(0.1 \mathrm{M}, \mathrm{pH} 7.4,4^{\circ} \mathrm{C}\right)$, and dissected tissue was frozen on dry ice. Retinas were pooled to obtain independent samples of sufficient size for analysis (one sample from 12 retinas of six animals) and homogenized and lysed in nondenaturing buffer [ $20 \mathrm{~mm}$ Tris, $\mathrm{pH} 8.0,137 \mathrm{~mm}$ $\mathrm{NaCl}, 1 \%(\mathrm{w} / \mathrm{v})$ Nonidet P-40, 10\% (v/v) glycerol containing $1 \mu \mathrm{g} / \mathrm{ml}$ leupeptin, $1 \mathrm{~mm}$ phenylmethylsulfonylfluoride (PMSF), $10 \mu \mathrm{g} / \mathrm{ml}$ aprotinin, and $0.5 \mathrm{~mm}$ sodium orthovanadate]. Separate aliquots of each lysate ( $1 \mathrm{ml}, 1 \mathrm{mg}$ total protein) were immunoprecipitated using either 5 $\mu \mathrm{l}$ anti-pan-trk serum or $5 \mu \mathrm{l}$ anti-Ptrk antibody $(0.2 \mathrm{mg} / \mathrm{ml})$ while they were rotated overnight at $4^{\circ} \mathrm{C}$ to capture trk receptors or phosphorylated trk receptors, respectively. After this, $60 \mu \mathrm{l}$ of a $50 \%$ suspension of protein $\mathrm{A}$ agarose beads was added to each sample, and samples were rotated at $4^{\circ} \mathrm{C}$ for $2 \mathrm{hr}$. Sample pellets containing the immunocomplexes were washed three times in lysis buffer and once in $\mathrm{ddH}_{2} \mathrm{O}$. After the final wash, pellets were resuspended in $25 \mu \mathrm{l}$ of sample buffer [ $62.5 \mathrm{~mm}$ Tris $\mathrm{HCl}, \quad \mathrm{pH} 6.8,2 \%(\mathrm{v} / \mathrm{v})$ SDS, $10 \% \quad(\mathrm{v} / \mathrm{v})$ glycerol, $5 \% \quad(\mathrm{v} / \mathrm{v})$ $\beta$-mercaptoethanol and $0.004 \%(\mathrm{w} / \mathrm{v})$ bromophenol blue], boiled for 5 min, electrophoresed on a $7.5 \%$ polyacrylamide gel, and transferred to a nitrocellulose membrane ( $0.4 \mu \mathrm{m}$ pore size). Pan-trk and Ptrk immunoprecipitates from the same sample of lysate were loaded into adjacent lanes on the gels. Each gel contained pan-trk and Ptrk immunoprecipitation (IP) products from the same number of samples of lysate from each genotype. Membranes were incubated with anti-trkB (1:500 dilution) overnight at $4^{\circ} \mathrm{C}$, washed, incubated with anti-mouse IgG peroxidase-conjugated antibody (1:2500 dilution), washed, and treated with ECL reagents (Amersham Biosciences) per the manufacturer's instructions. The ECL-treated membranes were placed in contact with blue-sensitive x-ray film (Molecular Technologies, St. Louis, MO), which when developed was scanned and processed for analysis using a densitometer (Molecular Dynamics; Personal Densitometer SI). Average pixel intensities of protein bands were measured and analyzed using Molecular Dynamics Imagequant, version 5.0 for Windows, and background pixel intensities were subtracted from protein band intensities to obtain corrected band intensities.

The statistical significance of genotype-associated, quantitative differences in the levels of $\operatorname{trkB}_{\mathrm{FL}}$ and phosphorylated $\operatorname{trkB}_{\mathrm{FL}}\left(\mathrm{PtrkB}_{\mathrm{FL}}\right)$ was assessed using the Wilcoxon signed-rank test. The significance of genotype-associated differences in the ratio of the $\operatorname{PtrkB}_{\mathrm{FL}}$ and $\operatorname{trkB} \mathrm{B}_{\mathrm{FL}}$ signals (an index of the fraction of $\operatorname{trkB}_{\mathrm{FL}}$ that is phosphorylated) was assessed using a Mann-Whitney $U$ test (two-tailed).

In control experiments, we demonstrated that our immunoprecipitation-Western blot procedure is linear over the range of signal intensities detected in these studies. Additional aliquots of lysate were prepared from WT mice and serially diluted by a factor of two at each dilution. Full-strength and diluted lysates were then immunoprecipitated using the pan-trk or Ptrk antibodies. Immunoprecipitation products obtained from different concentrations of the same lysate were then run on adjoining lanes on the same gel, and the intensity of the $\operatorname{trkB}_{\mathrm{FL}}$ and $\mathrm{PtrkB} \mathrm{FL}_{\mathrm{FL}}$ signals was determined as above. The results (data not shown) demonstrate that for both $\operatorname{trkB} \mathrm{BL}_{\mathrm{FL}}$ and $\mathrm{PtrkB}_{\mathrm{FL}}$, signal intensity is linear over at least a fourfold range of lysate dilution, whereas the signals measured in our experimental animals differed from those in normal WT mice only by a factor of 2, within the linear range of the assay (see Results).

Electron microscopy. The details of our procedures have been described previously (Williams et al., 1996) and are summarized here. Mice (see Table 1) were anesthetized with Avertin and perfused transcardially with $0.9 \%$ saline followed by glutaraldehyde/paraformaldehyde fixative. After postfixation, the optic nerves were dissected, osmicated, embedded, and sectioned at a standard distance from the optic disc. An unbiased sampling procedure was used to determine the number of axons in each optic nerve. The effects of genotype, sex, age, brain weight, and body weight on the number of optic nerve axons were determined using a multiple linear regression model. The significance of differences between WT and $\operatorname{trkB}_{\mathrm{FL}}{ }^{+/-}$mice with respect to the number of optic nerve axons was assessed using a two-tailed $t$ test.

These experiments were conducted in accordance with National Institutes of Health guidelines regarding the care and use of animals for experimental procedures.

\section{Results \\ Endogenous BDNF but not NT4 reduces the rate of developmental RGC death}

We examined the roles of BDNF and NT4 in modulating the rate of developmental RGC death by investigating the effects of null mutation of each ligand individually and of both together. On P2, there is no significant difference in the frequency of pyknotic RGC nuclei in WT $(0.96 \pm 0.11 \%)$ and $\mathrm{BDNF}^{+/+} \mathrm{NT}^{-/-}$ $(1.04 \pm 0.21 \%)$ mice $(p=0.4624)$ (Fig. 2$).$ In BDNF $^{+/-} \mathrm{NT} 4^{+/+}$ and $\mathrm{BDNF}^{-/-} \mathrm{NT}^{-1-}$ mice, respectively, the frequencies of pyknotic RGCs are 1.4-fold ( $1.31 \pm 0.06 \% ; p=0.0143)$ and 1.7 -fold (1.62 $\pm 0.35 \% ; p=0.009)$ that in WT mice (Fig. 2). Our data exclude the possibility that NT4 enhances the effects of BDNF on $\mathrm{RGC}$ death. If this were the case, one would expect that $\mathrm{BDNF}^{-1-}$ mice would have an effect on RGC death greater than or equal to that in $\mathrm{BDNF}^{+/-}$mice but a smaller effect than that in 

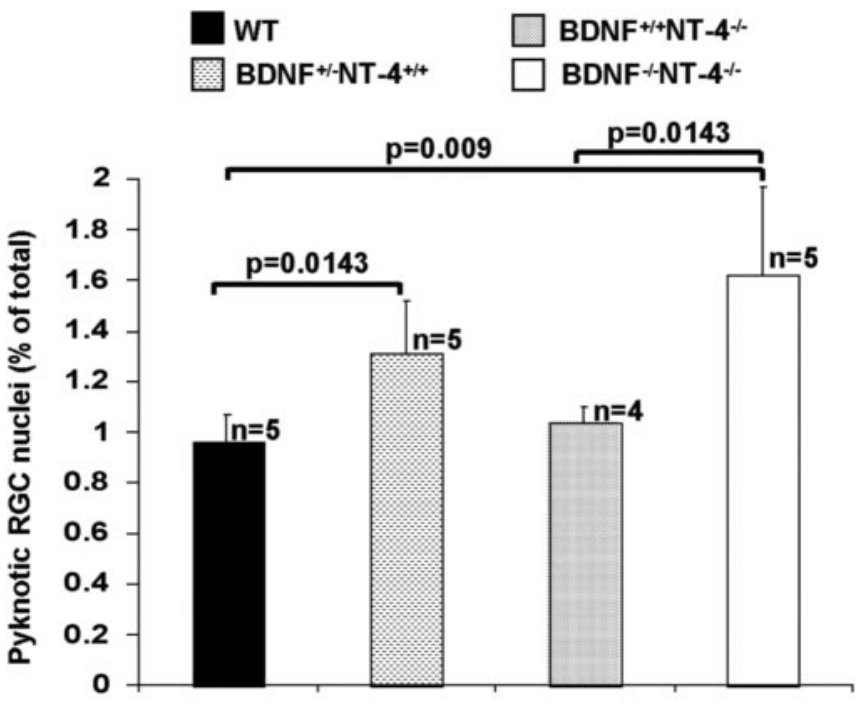

Figure 2. Frequency (see Materials and Methods) of pyknotic, DY-labeled RGCs in the retina on P2. Histograms represent $\mathrm{BDNF}^{+/+} \mathrm{NT} 4^{+/+}(\mathrm{WT}), \mathrm{BDNF}^{+/-} \mathrm{NT}^{+/+}, \mathrm{BDNF}^{+/+}$ $\mathrm{NT}^{-l-}$, and BDNF ${ }^{-1-} \mathrm{NT}^{-/-}$. $n$ indicates the number of cases in each group. $p$ values indicate significance of differences between groups joined by brackets.

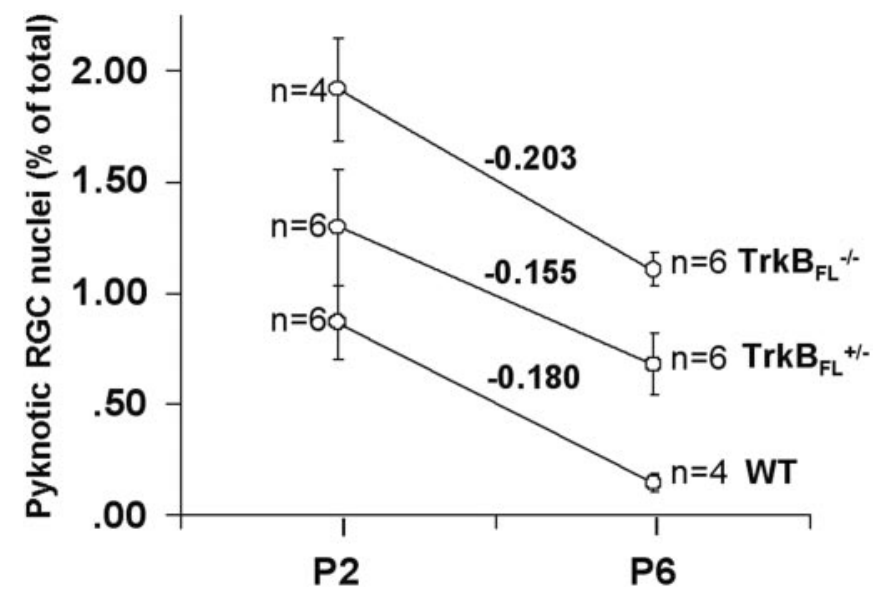

Figure 3. Temporal changes in the frequency of pyknotic RGCs. Data from $\mathrm{WT}, \mathrm{trkB}_{\mathrm{FL}}{ }^{+/-}$, and trkB $\mathrm{B}_{\mathrm{FL}}{ }^{-1-}$ mice obtained on $\mathrm{P} 2$ and $\mathrm{P} 6$. Also indicated are the slopes of the plots of pyknotic RGC frequency.

$\mathrm{BDNF}^{-/-} \mathrm{NT}^{-/-}$mice. There is no statistically significant difference between $\mathrm{BDNF}^{+/-} \mathrm{NT}^{+/+}$mice and $\mathrm{BDNF}^{-1-} \mathrm{NT} 4^{-1-}$ mice $(p=0.0854)$. Thus the effect of BDNF null mutation on RGC death is saturated, or almost so, in $\operatorname{BDNF}(+/-)$ mice, and additional null mutation of NT4 does not significantly enhance the effect. These data demonstrate that endogenous BDNF but not NT4, reduces the rate of developmental RGC death in vivo.

\section{$\operatorname{TrkB}_{\mathrm{FL}}$ receptor expression has a graded effect on} developmental RGC death

Examination of the effects of null mutation of the trkB catalytic domain tests the hypothesis that $\operatorname{trkB}_{\mathrm{FL}}$ receptor signaling modulates the rate of developmental RGC death. In WT mice, the frequency of pyknotic RGC nuclei falls from $0.87 \pm 0.18 \%$ on $\mathrm{P} 2$ to $0.15 \pm 0.04 \%$ on $\mathrm{P} 6$ (Fig. 3). On P2, in $\operatorname{trkB}_{\mathrm{FL}}{ }^{+/-}$and $\operatorname{trkB}_{\mathrm{FL}}{ }^{-1-}$ mice, respectively, the frequency of pyknotic RGCs is increased 1.5 -fold $(1.30 \pm 0.21 \% ; p=0.039)$ and 2.2 -fold $(1.92 \pm 0.23 \% ; p=0.0105)$ as compared with WT mice (Fig. 3). On $\mathrm{P} 6$, in $\operatorname{trkB}_{\mathrm{FL}}{ }^{+/-}$and $\operatorname{trkB}_{\mathrm{FL}}{ }^{-/-}$mice, respectively, the fre- quency of pyknotic RGCs is elevated 4.5 -fold ( $0.68 \pm 0.15 \%$; $p=$ $0.0105)$ and 7.4 -fold $(1.11 \pm 0.07 \% ; p=0.008)$, as compared with WT mice (Fig. 3). At both ages, the frequency of pyknotic RGCs is greater in homozygous than in heterozygous mutants (Fig. 3) ( $p=0.0105$ on P2; $p=0.004$ on P6). In all three genotypes, the frequency of pyknotic RGCs is greater on P2 than on P6, and the slopes of the plots of pyknotic RGC frequency as a function of age are similar among genotypes (WT $=-0.180 \%$ per day; $\operatorname{trkB}_{\mathrm{FL}}{ }^{+/-}=-0.155 \%$ per day; $\operatorname{trkB}_{\mathrm{FL}}{ }^{-1-}=-0.203 \%$ per day). Thus, on $\mathrm{P} 2$ and $\mathrm{P} 6$, null mutation of the $\operatorname{trkB}_{\mathrm{FL}}$ catalytic domain causes a dose-dependent increase in the rate of RGC death. This suggests that in vivo, trkB $\mathrm{FL}_{\mathrm{FL}}$ receptor signaling modulates the rate of developmental RGC death; however, at least between $\mathrm{P} 2$ and P6, the mutation does not alter the time constant of the developmental change in the rate of RGC death.

Null mutation of trkB $\mathrm{F}_{\mathrm{FL}}$ causes dose-dependent reductions in retinal trkB $B_{F L}$ protein and trkB phosphorylation

If $\operatorname{trkB} B_{\mathrm{FL}}$ signaling modulates the rate of developmental RGC death, then null mutations of the $\operatorname{trk} \mathrm{B}_{\mathrm{FL}}$ gene should also have a dose-dependent effect on the activation of $\operatorname{trkB}_{\mathrm{FL}}$, as indicated by the amount of $\operatorname{PtrkB}_{\mathrm{FL}}$. We measured the levels of trkB $\mathrm{FL}_{\mathrm{FL}}$ protein and $\mathrm{PtrkB}_{\mathrm{FL}}$ protein in $\mathrm{WT}, \operatorname{trkB}_{\mathrm{FL}}{ }^{+/-}$, and $\operatorname{trkB}_{\mathrm{FL}}{ }^{-1-}$ mice to determine whether this is the case.

Retinal tissue lysates from all three genotypes of mice were prepared, immunoprecipitated, and subjected to Western blot analysis, as described in Materials and Methods (Fig. 4A). There is a dose-dependent effect of the mutant gene on the retinal concentration of $\operatorname{trkB}_{\mathrm{FL}}$ protein (Fig. $4 B$ ). In $\operatorname{trkB}_{\mathrm{FL}}{ }^{+/-}$mice, the tissue concentration of $\operatorname{trkB}_{\mathrm{FL}}$ in the retinas is $51 \%$ of that in $\mathrm{WT}$ $(p=0.0277)$. There was no detectable $\operatorname{trkB}_{\mathrm{FL}}$ in the retinas of $\operatorname{trkB}_{\mathrm{FL}}{ }^{-1-}$ mice. The retinal level of $\operatorname{PtrkB}_{\mathrm{FL}}$ is reduced to $70 \%$ of its normal value in the retinas of $\operatorname{trkB}_{\mathrm{FL}}{ }^{+/-}$mice (Fig. $\left.4 C\right)(p=$ 0.0277), whereas there is no detectable $\operatorname{PtrkB}_{\mathrm{FL}}$ in the retinas of $\operatorname{trkB}_{\mathrm{FL}}{ }^{-1-}$ mice. In the retinas of WT mice (Fig. $4 D$ ), the PtrkB $_{\mathrm{FL}}$ / $\operatorname{trkB}_{\mathrm{FL}}$ signal ratio, a linear index of the fraction of $\operatorname{trkB}_{\mathrm{FL}}$ that is phosphorylated, is $0.39 \pm 0.13$. In the retinas of $\operatorname{trkB}_{\mathrm{FL}}{ }^{+/-}$mice, the $\mathrm{PtrkB}_{\mathrm{FL}} / \operatorname{trkB}_{\mathrm{FL}}$ signal ratio is increased to $0.55 \pm 0.06$ (Fig. $4 D)(p=0.0446)$. The relative amount of $\operatorname{trkB}_{\mathrm{FL}}$ phosphorylation increases in $\operatorname{trkB}_{\mathrm{FL}}{ }^{+/-}$mice because the decrease in $\operatorname{trkB}_{\mathrm{FL}}$ is relatively greater than the decrease in $\mathrm{PtrkB}_{\mathrm{FL}}$. The absence of a detectable band at $145 \mathrm{kDa}$ for both pan-trk and Ptrk IP products from lysates obtained from $\operatorname{trkB}_{\mathrm{FL}}{ }^{-/-}$mice demonstrates that the trkB antibody does not cross-react with retinal trkA or trkC.

Our data show that null mutation of the $\operatorname{trkB_{FL}}$ catalytic domain produces dose-dependent reductions in the absolute amounts of retinal trkB $\mathrm{FL}_{\mathrm{FL}}$ and $\mathrm{PtrkB}_{\mathrm{FL}}$. These changes are negatively correlated with the dose-dependent increases in the rate of RGC death in $\operatorname{trkB}_{\mathrm{FL}}$ mutant mice.

\section{Depletion of endogenous trkB ligands in the SC during the normal period of developmental RGC elimination increases the rate of RGC death}

TrkB-Fc injected into the SC depletes trkB ligands only at the injection site and for a limited time after treatment. Thus, intracollicular receptor body injection can be used to determine the role of endogenous, target-derived trkB ligands in modulating the rate of developmental RGC death. We examined the effects of intra-SC trkB-Fc injection at $20 \mathrm{hr}$ after treatment because previous studies (Ma et al., 1998) have shown that this is a latency at which increased BDNF/trkB signaling has an effect on the rate of RGC death. Twenty hours after injection of trkB-Fc, the frequency of DY-labeled, pyknotic RGC nuclei ( $1.7 \pm 0.34 \%)$ is 1.5 - 


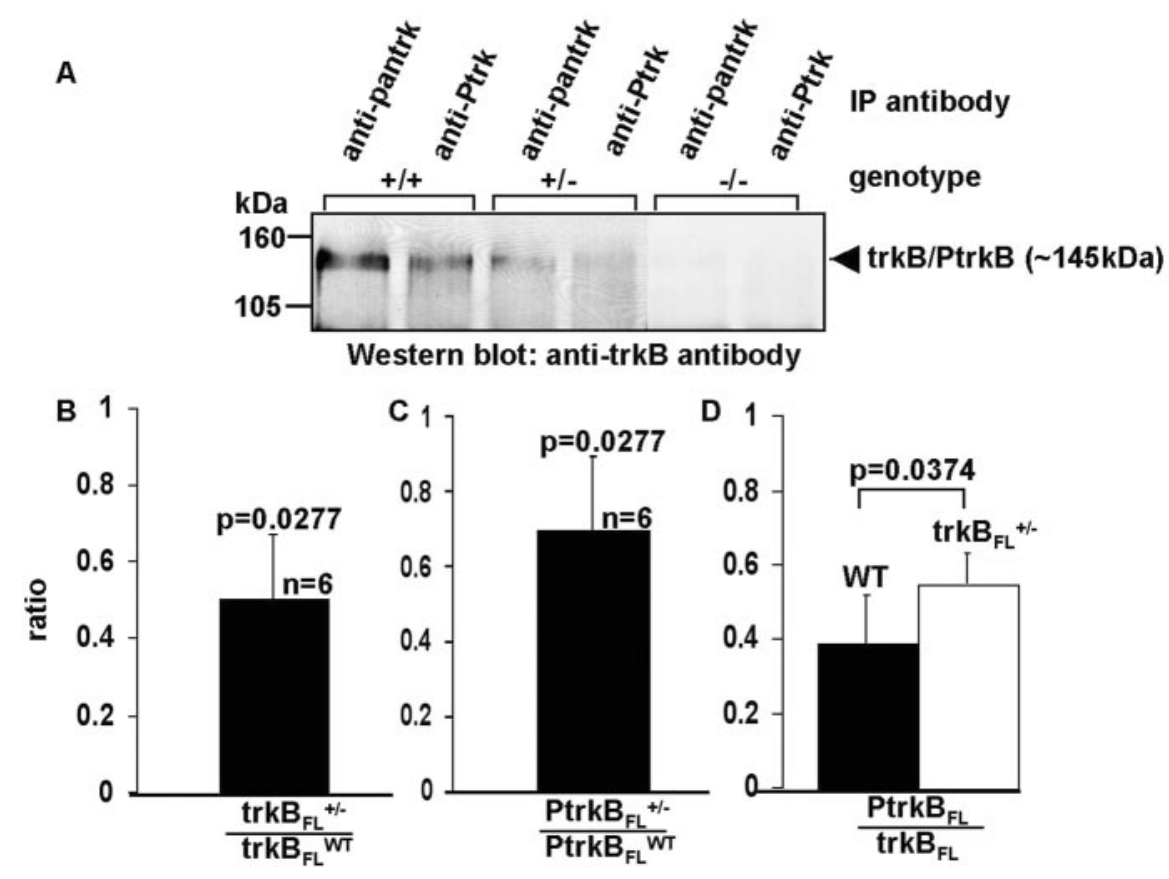

Figure 4. $A$, Immunoprecipitation-immunoblot analysis of trkB phosphorylation (activation). Lysates were obtained from the retinas of WT $(+/+)$, trkB $_{\mathrm{FL}}{ }^{+/-}$, and trkB $\mathrm{FL}^{-1-}$ mice, immunoprecipitated with anti-pan-trk or anti-Ptrk, and probed with an antibody against the extracellular domain of trkB. $B$, Ratio of retinal trkB $\mathrm{FL}_{\mathrm{FL}}$ in trkB $\mathrm{FL}_{\mathrm{FL}}^{+/-}$mice to retinal trkB $\mathrm{FL}_{\mathrm{L}}$ in WT mice. $C$, Ratio

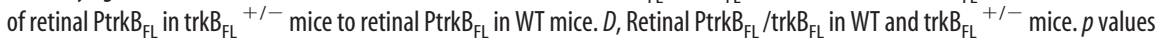
indicate significance of intergroup differences.

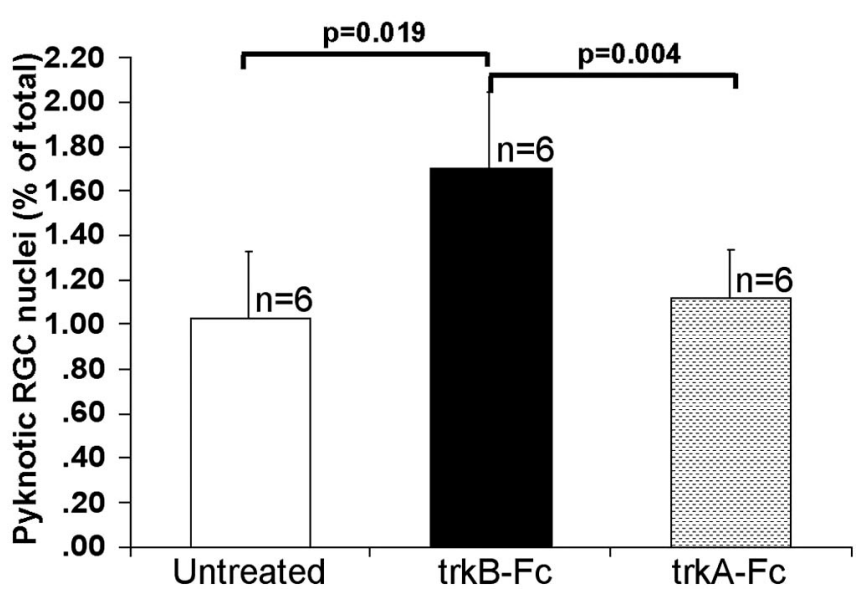

Figure 5. Frequency of pyknotic, DY-labeled RGCs in hamsters on P4. $n$ indicates the number of cases in each group. The frequency of pyknotic nuclei in trkB-Fc-treated hamsters differs significantly from that in untreated and trkA-Fc-treated hamsters, but there is no significant difference in frequency between untreated and trkA-Fc-treated hamsters (see Results). $p$ values indicate significance of intergroup differences.

and 1.7-fold higher, respectively, than in trkA-Fc-injected $(1.12 \pm 0.22 \% ; p=0.004)$ or untreated $(1.03 \pm 0.3 \% ; p=0.019)$ hamsters (Fig. 5). [These experiments were performed immediately after our original pharmacologic studies of the effects of exogenous BDNF (Ma et al., 1998) and thus used the same species, Mesocricetus auratus, the Syrian golden hamster. Mice were used in the other experiments of the present study because of the availability of signaling mutants. The trkB-Fc reagent is no longer available, so the experiments cannot be repeated in mice. There is no reason to believe that the results in mice would be any different.] The absence of a significant difference between trkA-Fctreated and untreated hamsters $(p=0.437)$ demonstrates that
(1) the effects of trkB-Fc are specific and cannot be attributed to all extracellular trk domains or to the Fc fragment of the fusion protein and (2) the injection procedure did not cause lesion-induced RGC pyknosis. Our data demonstrate that endogenous, target-derived trkB ligands reduce the rate of developmental RGC death.

\section{DY injection into the SC does not induce RGC death}

Intra-SC injection of DY could produce SC lesions or a toxic accumulation of DY in RGCs, either of which could elevate the rate of RGC death. If this were the case, it would be uncertain whether BDNF/trkB signaling modulates developmentally induced, lesion-induced, or toxicityinduced RGC death. To control for these possibilities, we treated WT mice with DY on P1 and killed them on P2, as above. There is no significant difference between untreated $(n=6)$ and DY-treated $(n=4)$ mice with respect to the frequency of pyknotic nuclei in the RGC layer, as revealed by Hoechst staining ( $p=0.89$ ) (Fig. 6). The possibility that RGC death is induced by DY injections in our mice treated and killed on $\mathrm{P} 2$ and $\mathrm{P} 6$, respectively, is excluded by our previous data (Ma et al., 1998) showing no effect of intra-SC DY injection on RGC death up to at least $3 \mathrm{~d}$ after injection and by results in cats (Innocenti, 1981) that demonstrate the viability of cortical neurons over many weeks after neonatal DY labeling. Thus our data demonstrate the effects of $\mathrm{BDNF} / \mathrm{trkB}$ signaling on developmentally, not lesion-induced or DY toxicity-induced, RGC death.

Reduced trkB $\mathrm{FL}_{\mathrm{FL}}$ signaling does not alter the number of RGCs in mature mice

The final number of RGCs is equal to the number produced less the number that die during development (equal to the integral of the rate of RGC death as a function of time). Thus the rate of RGC death at any particular age(s) does not necessarily predict the net amount of cell death or the final number of RGCs. Because the number of axons in the optic nerve is an accurate indicator of the number of RGCs (Williams et al., 1986), we assessed the effect of trkB signaling on the final number of RGCs by counting the number of axons in the optic nerves of mature $\mathrm{WT}$ and $\operatorname{trkB}_{\mathrm{FL}}+/-$ mice (Table 1). There is no significant difference between the number of axons in the optic nerves of WT mice $(63,322 \pm 4196)$ and the number of axons in the optic nerves of $\operatorname{trkB}_{\mathrm{FL}}{ }^{+/-}$mice $(67,654 \pm 6394 ; p=0.17)$, although, as shown above in neonatal $\operatorname{trkB}_{\mathrm{FL}}{ }^{+/-}$mice, the rate of RGC death is elevated compared with normal, and retinal trkB $\mathrm{B}_{\mathrm{FL}}$ phosphorylation is reduced.

We did not examine the number of optic nerve axons in trk$\mathrm{B}_{\mathrm{FL}}{ }^{-1-}$ mice because of potential interpretative difficulties. (1) If the number of axons were reduced, this might be attributed to the poor health status of $\operatorname{trkB}_{\mathrm{FL}}{ }^{-/-}$mice, because they waste and die by approximately $\mathrm{P} 14$. TrkB $\mathrm{FL}^{+/-}$mice thrive and grow normally and have a normal life span. (2) If there were no change in the number of optic nerve axons, it could be hypothesized that had 


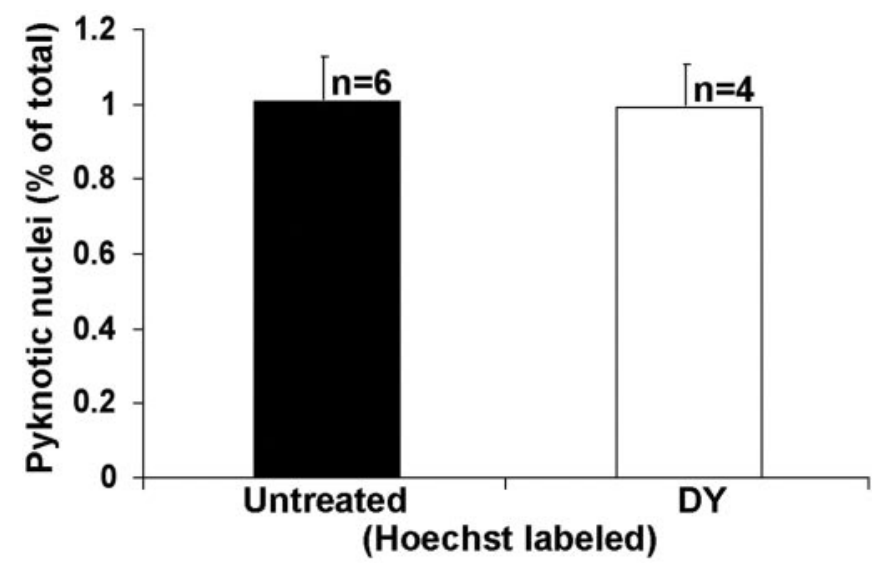

Figure 6. Comparison of the frequency of Hoechst dye-labeled pyknotic nuclei on P2 in untreated WT mice and WT mice injected with DY on P1. $n$ indicates the number of cases in each group.

Table 1. Number of axons in the optic nerve of wild-type and trkB ${ }_{\mathrm{FL}}{ }^{+/-}$mice

\begin{tabular}{lllllll}
\hline Animal & $\begin{array}{l}\text { Number of } \\
\text { axons (RGCs) }\end{array}$ & SEM & Sex & $\begin{array}{l}\text { Brain weight } \\
\text { (mg) }\end{array}$ & $\begin{array}{l}\text { Body } \\
\text { weight (gm) }\end{array}$ & Age (d) \\
\hline WT1 & 61169 & 4153 & F & 500.5 & 28.7 & 273 \\
WT2 & 71348 & 5872 & F & 547.6 & 27.8 & 265 \\
WT3 & 63474 & 5020 & F & & 28.1 & 226 \\
WT4 & 60839 & 5290 & M & 533.4 & 34.1 & 273 \\
WT5 & 66198 & 3567 & F & 522.7 & 28.7 & 274 \\
WT6 & 60992 & 4141 & F & 500.5 & 28.7 & 273 \\
WT7 & 59237 & 4003 & M & 553.6 & 44.7 & 274 \\
T1 & 79087 & 4046 & M & 515.1 & 36.8 & 265 \\
T2 & 69436 & 5816 & F & 508.9 & 31.6 & 216 \\
T3 & 60386 & 5817 & F & 516 & 36.8 & 265 \\
T4 & 64483 & 3991 & M & 468.2 & 32.3 & 216 \\
T5 & 67645 & 3217 & F & 522.9 & 28.6 & 265 \\
T6 & 64888 & 4490 & M & 549.2 & 34.7 & 276 \\
\hline WT Wild type.T trkB & $+/-$ & & & & &
\end{tabular}

the $\operatorname{trkB} \mathrm{BL}^{-1-}$ mice lived longer, the number of axons might subsequently have decreased.

\section{Discussion}

Endogenous, target-derived BDNF signaling through trkB $\mathrm{BL}_{\mathrm{FL}}$ alters the dynamics of developmental RGC death in vivo

The survival-promoting role of target-derived neurotrophins during normal development is well established for peripheral neurons (Oppenheim, 1991; Lewin and Barde, 1996) but is controversial for central neurons. The best documented example for central neurons is the effect of endogenous retinal BDNF on chick isthmo-optic neurons (von Bartheld and Johnson, 2001). TrkB signaling may regulate the death rate of immature geniculocortical neurons (Lotto et al., 2001). The dramatic reduction in the rate of developmental RGC death after intra-SC injection of BDNF (Ma et al., 1998) suggests that endogenous BDNF within the SC might inhibit the death of immature RGCs.

Here we examine the effects in developing RGCs of the two high-affinity trkB receptor ligands, BDNF and NT4. Null mutation of BDNF (alone or in combination with NT4), but not mutation of NT4 alone, increases the rate of developmental RGC death. Thus endogenous BDNF, but not NT4, reduces the rate of RGC death during normal development. We also determined that null mutation of the catalytic domain of trkB $\mathrm{FL}_{\mathrm{FL}}$ induces dosedependent increases in the rate of developmental RGC death on $\mathrm{P} 2$ and $\mathrm{P} 6$ and reductions in the level of $\mathrm{PtrkB}_{\mathrm{FL}}$ in the retina.
Because heterozygous null mutation of BDNF or $\operatorname{trk} \mathrm{B}_{\mathrm{FL}}$ increases the rate of RGC death on P2 and P6 without changing the final number of RGCs, the rate of RGC death should be subnormal at other ages, most likely shortening the epoch of RGC death. These effects show that BDNF, signaling through trkB $\mathrm{FL}_{\text {in }}$ RGCs, modulates the dynamics of developmental RGC death. P75 neurotrophin receptor mutation can also alter the dynamics of neuronal death (Bamji et al., 1998).

Because all cells in constitutive "knock-out" mice are affected by the mutation throughout life, data from those animals alone do not indicate at which site(s) or developmental stage(s) the mutation exerts its effect. When and on what cells do targetderived trkB ligands act to modulate the rate of RGC death at the developmental stages examined in this study? Several observations suggest that during the developmental epoch when RGCs are eliminated, target-derived $\mathrm{BDNF}$, binding to trkB receptors on RGC axon terminals, reduces the death rate of immature RGCs. (1) Depletion of trkB ligands by intra-SC injection of trkB-Fc receptor bodies increases the rate of developmental RGC death. The binding of trkB-Fc receptor bodies to trkB ligands is spatially restricted to the region of the injection and temporally restricted to a limited epoch beginning at the time of injection. (2) Intracerebral injection of trkB-Fc dramatically reduces trk phosphorylation at the injection site (Cabelli et al., 1997). Because trkA-Fc and trkB-Fc have the same specificity of binding to different neurotrophins as their respective native receptors (Shelton et al., 1995), the reduced phosphorylation demonstrates the binding of trkB ligands by trkB-Fc in vivo. (3) BDNF injected into the SC does not reduce the rate of developmental RGC death until after the injected BDNF accumulates in the retina (Ma et al., 1998), although intracellular messengers, notably $\mathrm{PtrkB}_{\mathrm{FL}}$ in signaling endosomes (Bhattacharyya et al., 1997; Watson et al., 1999) that are activated when BDNF binds to its receptors on RGC axon terminals, are probably cotransported to the retina with BDNF. Similarly, intra-ocularly injected BDNF acts with a delay to reduce the rate of developmental death of chick isthmooptic neurons (Primi and Clarke, 1996).

TrkB activation drops within a few hours when ligand is withdrawn in vitro and probably responds more rapidly in vivo (Knüsel et al., 1997); however, the fall in trkB activation induced by a single intra-SC injection of trkB-Fc, although rapid, is probably transient. Thus, the trkB-Fc-induced increase in RGC death rate may also be transient and may return to normal along a curve that parallels the recovery of trkB activation but is delayed by $12-20$ $\mathrm{hr}$, the latency required for increased BDNF/trkB signaling to reduce the RGC death rate (Ma et al., 1998). At the $20 \mathrm{hr}$ latency of this study, the RGC death rate may already have begun to fall. Thus, the $50-70 \%$ death rate increase induced by trkB-Fc is a minimum estimate of the effect of endogenous, target-derived trkB ligands.

Our data do not necessarily indicate that BDNF is the only target-derived factor that reduces the rate of developmental RGC death. Other neurotrophic factors that elevate intracellular cAMP levels may act synergistically with BDNF (Meyer-Franke et al., 1995). The action of multiple such target-derived factors may explain why the rate of RGC death is only $2.2-7.4 \times$ the normal rate in $\operatorname{trkB}_{\mathrm{FL}}{ }^{-1-}$ mice and only $1.7 \times$ the normal rate after intracollicular injection of trkB-Fc, although on a molar basis, the tissue concentration of trkB-Fc $(\sim 1000$-fold that of endogenous trkB) (Rodriguez-Tebar and Barde, 1988) was adequate to block the binding of trkB ligands to endogenous trkB receptors. An alternative explanation of why the effects of trkB-Fc treatment were not greater, that endogenous trkB might have a much 
greater affinity for its ligands than trkB-Fc, has been excluded previously (Shelton et al., 1995). Because trkB mRNA and protein are expressed in the rodent SC (Altar et al., 1994; Yan et al., 1997; our study), depletion of intra-SC BDNF might also act by reducing either (1) the secretion by SC cells of other factors that slow the rate of RGC death or (2) the density of receptors for those factors on RGC axon terminals (Wyatt and Davies, 1993).

The effects of trkB-Fc injection render extremely unlikely the possibility that a reduced rate of clearance of pyknotic nuclei contributes to the increased frequency of pyknotic RGCs in mice with null mutations of $\mathrm{BDNF}$ or trkB $\mathrm{BL}_{\mathrm{FL}}$. Intra-SC injection of trkB-Fc causes similar increases in the frequency of pyknotic RGC nuclei but cannot affect the clearance of pyknotic debris by phagocytes in the retina, from which the injection site is effectively isolated. Thus, null mutation-induced increases in the frequency of pyknotic nuclei are caused by increases in the rate of RGC death.

Several observations exclude the possibility that the elevated RGC death rate in mice with null mutations of $B D N F$ or $\operatorname{trkB}_{\mathrm{FL}}$ is caused by malnutrition or other nonspecific effects rather than by the direct effects of $\mathrm{BDNF} / \mathrm{trkB}_{\mathrm{FL}}$ signaling on RGCs. (1) Mice that are heterozygous for null mutations of $\mathrm{BDNF}$ or trkB $\mathrm{FL}_{\mathrm{FL}}$ gain weight normally, have a normal life span, and have elevated rates of developmental RGC death. (2) The final number of RGCs is normal in mice with null mutations of BDNF (Cellerino et al., 1997) or trkB (Rohrer et al., 2001; our study), despite the elevated RGC death rate earlier in life. (3) Although homozygous mutants for $\mathrm{BDNF}$ and $\operatorname{trkB}_{\mathrm{FL}}$ waste and die during the second or third postnatal week, these animals have elevated rates of RGC death as early as P2, before wasting occurs.

It is unlikely that the elevated RGC death rate in mice with null mutations of $\operatorname{trk} \mathrm{B}_{\mathrm{FL}}$ or BDNF is caused by mutation-induced increases in RGC proliferation before the period of RGC death. (1) $\mathrm{BDNF} /$ trkB $_{\mathrm{FL}}$ signaling is mitogenic (Represa et al., 1993; Zigova et al., 1998). Thus, if proliferation is abnormal in null mutants, it is likely to be reduced. (2) TrkB-Fc treatment of hamsters on P3, after RGC proliferation has terminated (embryonic day 11) (Sengelaub et al., 1986), causes increases in the RGC death rate comparable with those induced by null mutation of $\mathrm{BDNF}$ or $\operatorname{trkB}_{\mathrm{FL}}$.

\section{Mechanisms of the effects of $\mathrm{BDNF} / \mathrm{trkB}_{\mathrm{FL}}$ on RGC death dynamics}

Ligand binding to trkB $\mathrm{B}_{\mathrm{FL}}$ exerts its effects by $\operatorname{trkB} \mathrm{B}_{\mathrm{FL}}$ autophosphorylation and subsequent activation of at least two intracellular signaling pathways (Atwal et al., 2000; Kaplan and Miller, $1997,2000)$. As the dosage of mutant $\operatorname{trkB}_{\mathrm{FL}}$ increases, the accompanying increase in RGC death and decrease in trkB $\mathrm{FL}_{\mathrm{FL}}$ activation in the retina (assessed in phosphorylation assays) provide evidence for the modulation of RGC death rate by activated trkB $\mathrm{FL}_{\mathrm{FL}}$ receptors transported to RGC somata from RGC axon terminals in the SC. Because the molar tissue concentration of trkB exceeds by several orders of magnitude that of BDNF (Rodriguez-Tebar and Barde, 1988), it is surprising that trkB $\mathrm{B}_{\mathrm{FL}}$ phosphorylation is diminished (by $30 \%$ ) in the retinas of $\operatorname{trkB}_{\mathrm{FL}}{ }^{+/-}$mice, in which trkB $B_{\mathrm{FL}}$ is reduced by only $49 \%$. Reductions in (1) the ratio of $\operatorname{trkB}_{\mathrm{FL}}$ to truncated $\operatorname{trkB}\left(\operatorname{trk} \mathrm{B}_{\mathrm{T}}\right)$, which lacks a catalytic domain, or (2) the retrograde transport of $\mathrm{BDNF} / \mathrm{PtrkB} \mathrm{BL}_{\mathrm{FL}}$ complexes from RGC axon terminals to somata are possible explanations.

\section{Dynamics of RGC death are BDNF/trkB $\mathrm{FL}_{\mathrm{FL}}$ dependent, whereas RGC number is not}

On P2 and P6, null mutation of $\operatorname{trkB}_{\mathrm{FL}}$ alone or BDNF (alone or in combination with NT4) increases the rate of developmental RGC death; however, null mutation of trkB $\mathrm{FL}_{\mathrm{FL}}$ alone (present results) or in combination with $\operatorname{trkB}_{\mathrm{T}}$ (Rohrer et al., 2001), or of BDNF alone (Cellerino et al., 1997), does not alter the final number of RGCs that remain after RGC death is complete. Thus the cellular mechanisms controlling the dynamics of developmental RGC death are BDNF/trkB-dependent, whereas those that regulate the final number of RGCs are BDNF/trkB independent. The Pearl mutation (Williams et al., 1990) also alters the dynamics of RGC death but not the final RGC number; this is difficult to interpret because the action of the gene product is unknown.

In studies of the mechanisms of developmental or injuryrelated cell death, it is often assumed that various measures of the rate of cell death are accurate indicators of the final number of neurons that will remain after cell death ceases. At least with respect to the actions of $\mathrm{BDNF} / \mathrm{trkB}_{\mathrm{FL}}$ on developing RGCs, this is not true. This is significant for the design and interpretation of functional studies of neurotrophic factors. In assessing the neurotrophic actions of extracellular molecules on a target cell population, one must distinguish between effects on the dynamics of cell elimination and on aggregate cell death-survival.

\section{References}

Alcantara S, Frisén J, del Rio JA, Soriano E, Barbacid M, Silos-Santiago I (1997) TrkB signaling is required for postnatal survival of CNS neurons and protects hippocampal and motor neurons from axotomy-induced cell death. J Neurosci 17:3623-3633.

Allendoerfer KL, Cabelli RJ, Escandon E, Kaplan DR, Nikolics K, Shatz CJ (1994) Regulation of neurotrophin receptors during the maturation of the mammalian visual system. J Neurosci 14:1795-1811.

Altar CA, Siuciak JA, Wright P, IP, N. Y., Lindsay RM, Wiegand SJ (1994) In situ hybridization of trkB and trkC receptor mRNA in rat forebrain and association with high-affinity binding of $\left[{ }^{125} \mathrm{I}\right]$ BDNF and $\left[{ }^{125} \mathrm{I}\right] \mathrm{NT} 4 / 5$ and $\left[{ }^{125} \mathrm{I}\right]$ NT-3. Eur J Neurosci 6:1389-1405.

Atwal JK, Massie B, Miller FD, Kaplan DR (2000) The trkB-Shc site signal neuronal survival and local axon growth via MEK and PI3-kinase. Neuron 27:265-277.

Bamji SX, Majdan M, Pozniak CD, Belliveau DJ, Aloyz R, Kohn J, Causing CG, Miller FD (1998) The p75 neurotrophin receptor mediates neuronal apoptosis and is essential for naturally occurring sympathetic neuron death. J Cell Biol 140:911-923.

Bennett JL, Zeiler SR, Jones KR (1999) Patterned expression of BDNF and NT-3 in the retina and anterior segment of the developing mammalian eye. Invest Ophthalmol Vis Sci 40:2996-3005.

Bhattacharyya A, Watson FL, Bradlee TA, Pomeray SL, Stiles CD, Segal RA (1997) Trk receptors function as rapid retrograde signal carriers in the adult nervous system. J Neurosci 17:7007-7016.

Bibel M, Barde Y-A (2000) Neurotrophins: key regulators of cell fate and cell shape in the vertebrate nervous system. Genes Dev 14:2919-2937.

Cabelli RJ, Shelton DL, Segal RA, Shatz CJ (1997) Blockade of endogenous ligands of trkB inhibits formation of ocular dominance columns. J Neurosci 19:63-76.

Castillo Jr B, del Cerro M, Breakefield XO, Firm DM, Barnstable CJ, Dean DO, Bohn MC (1994) Retinal ganglion cell survival is promoted by genetically modified astrocytes designed to secrete brain-derived neurotrophic factor (BDNF). Brain Res 647:30-36.

Cellerino A, Carroll P, Thoenen H, Barde Y (1997) Reduced size of retinal ganglion cell axons and hypomyelination in mice lacking brain-derived neurotrophic factor. Mol Cell Neurosci 9:397-408.

Cohen-Cory S, Fraser SE (1994) BDNF in the development of the visual system of Xenopus. Neuron 12:747-761.

Cohen-Cory S, Escandon E, Fraser SE (1996) The cellular patterns of BDNF and trkB expression suggest multiple roles for BDNF during Xenopus visual system development. Dev Biol 179:102-115.

Conover JC, Erickson JT, Katz DM, Bianchi LM, Poyeymirou WT, McClain J, Pan L, Helgren M, Ip NY, Boland P, Friedman B, Wiegand S, Vejsada R, 
Kato AC, DeChiara TM, Yancopoulos GD (1995) Neuronal defects, not involving motor neurons, in mice lacking BDNF and/or NT4. Nature 375:235-238.

Ernfors P, Merlio J-P, Persson H (1992) Cells expressing mRNA for neurotrophins and their receptors during embryonic rat development. Eur J Neurosci 4:1140-1158.

Escandon E, Soppet D, Rosenthal A, Mendoza-Ramirez J-L, Szonyi E, Burton LE, Henderson CE, Parada LF, Nikolics K (1994) Regulation of neurotrophin receptor expression during embryonic and postnatal development. J Neurosci 14:2054-2068.

Fournier AE, Beer J, Arregui CO, Essagian C, Aguayo AJ, McKerracher L (1997) Brain-derived neurotrophic factor modulates GAP-43 but not Tal expression in injured retinal ganglionic cells of adult rats. J Neurosci Res 47:561-572.

Frost DO, Ma Y-T, Hsieh T, Forbes ME, Johnson JE (2001) Developmental changes in BDNF protein levels in the hamster retina and superior colliculus. J Neurobiol 49:173-187.

Garner AS, Menegay HJ, Boeshore KL, Xie X-Y, Voci JM, Johnson JE, Large $\mathrm{TH}$ (1996) Expression of trkB receptor isoforms in the developing avian visual system. J Neurosci 16:1740-1752.

Ghosh A, Carnahan J, Greenberg ME (1994) Requirement for BDNF in activity-dependent survival of cortical neurons. Science 263:1618-1623.

Hallbook F, Backstrom A, Kullander K, Ebendal T, Carri N (1996) Expression of neurotrophins and trk receptors in the avian retina. J Comp Neurol 364:664-676.

Harvey AR, Robertson D (1992) Time-course and extent of retinal ganglion cell death following ablation of the superior colliculus in neonatal rats. J Comp Neurol 325:83-94.

Harvey AR, Robertson D, Cole KS (1990) Direct visualization of death of neurons projecting to specific targets in the developing rat brain. Exp Brain Res 80:213-217.

Herzog K, von Bartheld C (1998) Contributions of the optic tectum and the retina as sources of brain-derived neurotrophic factor for retinal ganglion cells in the chick embryo. J Neurosci 18:2891-2906.

Hofer M, Pagluisi SR, Hohn A, Liebrock J, Barde Y-A (1990) Regional distribution of brain-derived neurotrophic factor mRNA in the adult mouse brain. EMBO J 9:2459-2464.

Innocenti GM (1981) Growth and reshaping of axons in the establishment of visual callosal connections. Science 218:824-827.

Jelsma TN, Friedman HH, Berkelaar M, Bray GM, Aguayo AJ (1993) Different forms of the neurotrophin receptor trkB mRNA predominate in rat retina and optic nerve. J Neurobiol 24:1207-1214.

Johnson JE, Barde Y-A, Schwab M, Thoenen H (1986) Brain-derived neurotrophic factor supports the survival of cultured rat retinal ganglion cells. J Neurosci 6:3031-3038.

Johnson JE, Forbes ME, Anstrom J, Jan Q (2003) Mismatch between BDNF transcript and protein in the developing chick visual system as measured by a novel ECLIA. J Neurosci, in press.

Jones KR, Farinas I, Backus C, Reichardt LF (1994) Targeted disruption of the BDNF gene perturbs brain and sensory neuron development but not motor neuron development. Cell 76:989-999.

Kaplan DR, Miller FD (1997) Signal transduction by the neurotrophin receptors. Curr Opin Cell Biol 9:213-221.

Kaplan DR, Miller FD (2000) Neurotrophin signal transduction in the nervous system. Curr Opin Neurobiol 10:381-391.

Keizer K, Kuypers HG, Huisman AM, Dann O (1983) Diamidino yellow dihydrochloride (DY.2HCl): a new fluorescent retrograde neuronal tracer which migrates only very slowly out of the cell. Exp Brain Res 51:179-191.

Klein R, Smeyne RJ, Wurst W, Long LK, Auerbach BA, Joyner AL, Barbacid M (1993) Targeted disruption of the trkB neurotrophin receptor gene results in nervous system lesions and neonatal death. Cell 75:113-122.

Knüsel B, Gao H, Okazaki T, Yoshida T, Mori N, Hefti F, Kaplan DR (1997) Ligand-induced down-regulation of TRK messenger RNA, protein and tyrosine phosphorylation in rat cortical neurons. Neuroscience 78:851-862.

Koide T, Takahashi JB, Hoshimaru M, Kojima M, Otsuka T, Asahi M, Kikuchi $\mathrm{H}$ (1995) Localization of trkB and low-affinity nerve growth factor receptor mRNA in the developing rat retina. Neurosci Lett 185:183-186.

Korsching S (1993) The neurotrophic factor concept: a reexamination. J Neurosci 13:2739-2748.

Lewin GR, Barde Y-A (1996) Physiology of the neurotrophins. Annu Rev Neurosci 19:289-317.
Linden R, Esberard EL (1987) Displaced amacrine cells in the ganglion cell layer of the hamster retina. Vision Res 27:1071-1076.

Linden R, Pinto LH (1985) Developmental genetics of the retina: evidence that the pearl mutation in the mouse affects the time course of natural cell death in the ganglion cell layer. Exp Brain Res 60:79-86.

Lotto R, Asavaritikrai P, Vali L, Price DJ (2001) Target-derived neurotrophic factors regulate the death of developing forebrain neurons after a change in their trophic requirements. J Neurosci 21:3904-3910.

Ma Y-T, Hsieh T, Forbes ME, Johnson JE, Frost DO (1998) BDNF injected into the superior colliculus reduces developmental retinal ganglion cell death. J Neurosci 18:2097-2107.

Meyer-Franke A, Kaplan M, Pfrieger F, Barres B (1995) Characterization of the signaling interactions that promote the survival and growth of developing retinal ganglion cells in culture. Neuron 15:805-819.

Minichiello L, Klein R (1996) TrkB and trkC neurotrophin receptors cooperate in promoting survival of hippocampal and cerebellar granule neurons. Genes Dev 10:2849-2858.

Okazawa H, Kamei M, Imafuku I, Kanazawa I (1994) Gene regulation of trkB and trkC in the chick retina by light/darkness exposure. Oncogene 9:1813-1818.

Oppenheim RW (1991) Cell death during development of the nervous system. Annu Rev Neurosci 14:453-501.

Perez M-TR, Caminos E (1995) Expression of brain-derived neurotrophic factor and of its functional receptor in neonatal and adult rat retina. Neurosci Lett 183:96-99.

Pollock GS, Vernon E, Forbes ME, Yan Q, Ma Y-T, Hsieh T, Robichon R, Frost DO, Johnson JE (2001) Modulation of BDNF mRNA and protein levels by early visual experience and diurnal rhythms. J Neurosci 21:3923-3931.

Primi M-P, Clarke PGH (1996) Retrograde neurotrophin-mediated control of neuron survival in the developing central nervous system. Dev Neurosci 7:473-476.

Rehen SK, Linden R (1994) Apoptosis in the developing retina: paradoxical effects of protein synthesis inhibition. Braz J Med Biol Res 27:1647-1651.

Represa J, Avila MA, Romero G, Mato JM, Giraldez F, Varela-Nieto I (1993) Brain-derived neurotrophic factor and neurotrophin-3 induce cell proliferation in the cochleovestibular ganglion through a glycosylphosphatidylinositol signaling system. Dev Biol 159:257-265.

Rickman DW, Brecha N (1995) Expression of the proto-oncogene, trk, receptors in the developing rat retina. Vis Neurosci 12:215-222.

Rodriguez-Tebar R, Barde Y-A (1988) Binding characteristics of brainderived neurotrophic factor to its receptors on neurons from the chick embryo. J Neurosci 8:3337-3342.

Rodriguez-Tebar A, de la Rosa EJ, Arribas A (1993) Neurotrophin-3 receptors in the developing chick retina. Eur J Biochem 211:789-794.

Rohrer B, Lavail MM, Jones KR, Reichardt LF (2001) Neurotrophin receptor trkB activation is not required for the postnatal survival of retinal ganglion cells in vivo. Exp Neurol 172:81-91.

Schwartz PM, Borghesani PR, Levy RL, Pomeroy SL, Segal RA (1997) Abnormal cerebellar development and foliation in BDNF-/- mice reveals a role for neurotrophins in CNS patterning. Neuron 19:269-281.

Sengelaub DR, Dolan RP, Finlay BL (1986) Cell generation, death and retinal growth in the development of the hamster retinal ganglionic cell layer. J Comp Neurol 246:527-543.

Shelton DL, Sutherland J, Gripp J, Camerato T, Armanini MP, Philips HS, Carroll K, Spencer SD, Levinson AD (1995) Human trks: molecular cloning, tissue distribution, and expression of extracellular domain immunoadhesins. J Neurosci 15:477-491.

Suzuki A, Nomura S, Morii E, Fukuda Y, Kosaka J (1998) Localization of mRNAs for trkB isoforms and p75 in rat retinal ganglion cells. J Neurosci Res 54:27-37.

Thanos S, Bahr M, Barde Y-A, Vanselow J (1988) Survival and axonal elongation of adult rat retinal ganglion cells. Eur J Neurosci 1:19-26.

Ugolini G, Cremisi F, Maffei L (1995) TrkA, trkB and p75 expression is developmentally regulated in the rat retina. Brain Res 704:121-124.

von Bartheld CS, Johnson JE (2001) Target-derived BDNF (brain-derived neurotrophic factor) is essential for the survival of developing neurons in the isthmo-optic nucleus. J Comp Neurol 433:550-564.

Watson FL, Heerssen HM, Moheban DB, Lin MZ, Sauvageot CM, Bhattacharyya A, Pomeray SL, Segal RA (1999) Rapid nuclear responses to target-derived neurotrophins require retrograde transport of ligandreceptor complex. J Neurosci 19:7889-7900. 
Wetmore C, Ernfors P, Persson H, Olson L (1990) Localization of brainderived neurotrophic factor mRNA to neurons in the brain by in situ hybridization. Exp Neurol 109:141-152.

Williams MA, Piñon LGP, Linden R, Pinto LH (1990) The pearl mutation accelerates the schedule of natural cell death in the early postnatal retina. Exp Brain Res 82:393-400.

Williams RW, Bastiani MJ, Lia B, Chalupa LM (1986) Growth cones, dying axons, and developmental fluctuations in the fiber population of the cat's optic nerve. J Comp Neurol 246:32-69.

Williams RW, Strom RC, Rice DS, Goldowitz D (1996) Genetic and environmental control of variation in retinal ganglion cell number in mice. J Neurosci 16:7193-7205.

Wyatt S, Davies AM (1993) Regulation of expression of mRNAs encoding the nerve growth factor receptors p75 and trkA in developing sensory neurons. Development 119:635-648.

Yan Q, Radeke MJH, Matheson CR, Talvenheimo J, Welcher AA, Feinstein SC (1997) Immunocytochemical localization of trkB in the central nervous system of the adult rat. J Comp Neurol 378:135-157.

Young R (1984) Cell death during differentiation of the retina in the mouse. J Comp Neurol 229:362-373.

Zanellato A, Comelli MC, Dal Toso R (1993) Developing rat retinal ganglion cells express the functional NGF receptor p140 trkA. Dev Biol 159:105-113

Zigova T, Pencea V, Wiegand SJ, Luskin MB (1998) Intraventricular administration of BDNF increases the number of newly generated neurons in the adult olfactory bulb. Mol Cell Neurosci 11:234-245. 